Revista Brasileira de Agricultura Irrigada v.11, nº.5, p. 1700 - 1706, 2017

ISSN 1982-7679 (On-line)

Fortaleza, CE, INOVAGRI - http://www.inovagri.org.br

DOI: $10.7127 /$ rbai.v11n500760

Protocolo 760.17 - 23/05/2017 Aprovado em 31/08/2017

\title{
COMMERCIAL PERFORMANCE OF RABANET CULTIVATED IN ENVIRONMENT PROTECTED UNDER WATER BLADES
}

Anderson Dias Vaz de Souza ${ }^{1}$, Janaína Borges de Azevedo França ${ }^{2}$, Adriana Rodolfo da Costa $^{1}$, Frederico Antonio Loureuro Soares ${ }^{2}$, Muza Vieira do Carmo ${ }^{2}$

\begin{abstract}
The rabanet, being a tuber, is generated in the sub-superficial layer of the soil, and for this reason the observation and control of the water characteristics of the same is of fundamental importance. Thus, the objective of this study was to evaluate the effect of water slides depth on the commercial performance of radish cultivated in protected environment. The experiment was installed in a greenhouse of the State University of Goiás - UEG, Camps Ipameri. The design was the randomized blocks in factorial scheme. The treatments were composed of the combination of cultivars (Cometo and Giant Crimson) and percentage of available water in the soil (20, 40, 60, 80 and 100\%) in four blocks, comprising 40 experimental units, consisting of $4 \mathrm{dm}^{-3}$ vessels. They were evaluated at the time of harvest: plant height, leaf number, root length, fresh and dry mass of shoot and root, and root length. The leaf effect was significant for the length, fresh and dry mass of the root, the optimum blades were $71.79 \%, 71.04 \%$ and $62.31 \%$, respectively. The effect of cultivars was observed for the root dry mass variable, and cultivar Cometo presented the best performance.
\end{abstract}

Keywords: hydrical stress, irrigation management, Raphanus sativus L.

\section{DESEMPENHO COMERCIAL DE RABANETE CULTIVADO EM AMBIENTE PROTEGIDO SOB LÂMINAS DE ÁGUA}

\section{RESUMO}

O rabanete, por ser um tubérculo, é gerado na camada sub superficial do solo, e por isso a observação e controle das características hídricas do mesmo é de fundamental importância. Sendo assim, o objetivo deste estudo foi de avaliar o efeito de lâminas de água sobre o desempenho comercial do rabanete cultivado em ambiente protegido. O experimento foi instalado em casa de vegetação da Universidade Estadual de Goiás - UEG, Câmpus Ipameri. O delineamento adotado foi o em blocos casualizados em esquema fatorial, cujos tratamentos foram compostos da combinação de cultivares (Cometo e Crimson Gigante) e percentual de

\footnotetext{
${ }^{1}$ Universidade Estadual de Goiás - UEG, e-mail: andersondias_99@hotmail.com, adriana.costa@ueg.br

${ }^{2}$ IF Goiano Campus Rio Verde, e-mail: janainaborgesdeazevedofranca@gmail.com, fredalsoares@hotmail.com, mcvmuza@bol.com.br
} 
água disponível no solo (20, 40, 60, 80 e 100\%), dispostos em quatro blocos, perfazendo 40 unidades experimentais, constituídas de vasos de $4 \mathrm{dm}^{-3}$. Foram avaliados: altura da planta, número de folhas, comprimento da raiz, massa fresca e seca da parte aérea e raiz, diâmetro da raiz. O efeito de lâmina foi significativo para o comprimento, massa fresca e seca da raiz, sendo as lâminas ótimas as de 71,79\%, 71,04\% e 62,31\%, respectivamente. O efeito de cultivares foi observado para a variável massa seca de raiz, sendo a cultivar Cometo a que apresentou melhor desempenho.

Palavras-chave: estresse hídrico, manejo da irrigação, Raphanus sativus L.

\section{INTRODUCTION}

The development of plants is greatly influenced by the availability of water in the soil, since it plays many functions in this process. It acts as a constituent, solvent, reagent, maintains molecular structures, turgescence and thermally regulates plant tissues (MORENOFONCECA, 2009).

Alishah \& Ahmadikhah (2009), Mention that the water deficit in the soil is considered one of the main limiting factors to the development of the plant and can be aggravated by global climate change.

The cultivation of vegetables is strongly influenced by soil water characteristics. The abusive amount of water is harmful, however, soil moisture and water deficiency are some of the main limiting factors to high productivity and product quality (SILVA \& MAROUELLI, 1998).

The evaluation of the tolerance of a plant to the water stress can be carried out by means of the measurement of the leaf area and analysis of the accumulation of dry matter in the area (PIMENTEL, 2004).

Silva \& Marouelli, (1998), argue that vegetables grown under field conditions or in protected environments have their development intensely influenced by soil moisture conditions. Water deficiency is usually the most limiting factor in obtaining high productivity and good quality products, but excess can also be harmful. Irrigation may represent a possibility of control of soil water characteristics. There are three categories in which irrigation management methods fit: climatic parameters; Soil moisture and soil water potential; And measures of water potential in plants.
The radish (Raphanus sativus L.) is characterized as a rustic crop which, as a function of the short cycle, becomes a rotation option among the longer cycle crops. Its implantation serves as source of extra income, mainly in small properties allocated in green belts of big cities (JÚNIOR \& VENZON, 2007).

Since the tuber is generated in the subsurface layer of the soil, the observation and control of the water characteristics of the soil is of fundamental importance (SILVA et. al, 2012). Pinheiro et al. (2012), mention that throughout the development cycle of the crop it is necessary to take extreme care with the irrigation, not being able to be cultivated with excess water and, at the same time, not being able to occur fluctuations in the humidity of the ground, fact that can cause cracks becoming inadequate to trade.

Among the advantages of cultivating the radish crop, it is worth noting the ease of operation, relatively low cost and satisfactory results for the estimation of the water demand of the crops (SAAD \& SCALOPPI, 1988; KLAR, 1991).

In view of this, this project aimed to evaluate the effect of water stress caused by the reduction of water availability in the soil on the development and production of radish in a protected environment.

\section{MATERIAL AND METHODS}

The experiment was carried out in a greenhouse at the State University of Goiás UEG, Ipameri Camps. At $17^{\circ} 43^{\prime}$ South latitude and $48^{\circ} 22^{\prime}$ West longitude and $800 \mathrm{~m}$ level. The climate of the region according to the classification of Köppen is defined as Tropical 
Humid (AW), consisting of high temperatures with rains in summer and dry in winter.

The experiment was conducted from March to April 2017. Polyethylene vessels with a capacity of $4 \mathrm{dm}^{3}$ were used. The soil used was classified as Dystrophic Red-Yellow Latosol (EMBRAPA, 2006). The soil was destorroado, passed in $2 \mathrm{~mm}$ sieve and homogenized. The application of chemical fertilizers to the vessels was carried out according to the methodology proposed by NOVAIS et al., (1991) for controlled environment.

The soil moisture in the field capacity (CC) at the tension of $0.01 \mathrm{MPa}$ and the soil moisture at the permanent wilting point (PMP) at $1.5 \mathrm{MPa}$ tension, as well as the soil density, accordance with the methodologies EMBRAPA, (1997).

The experiment will be installed in a randomized complete block design, analyzed in a 2 x 5 factorial scheme with four replications.

The treatments were composed of the combination of varieties (Crimson and Cometo) $\mathrm{x}$ percentage of available water in the soil (20, 40, 60, 80 and 100\%).

The water deficit was started 3 days after sowing to allow the establishment of the plants. The irrigation slides were based on weighing lysimetry, where a known volume of water was placed.

The irrigations were based on determination of the weight of each experimental unit in the field capacity. Before sowing, the vessels were saturated with water and left in free drainage until they reached the moisture in the field capacity.

At the end of each day, the experimental units were weighed in an electronic scale, and the water required for each treatment, that is, in the $100 \%$ AD blade, will be returned to the initial weight (weight in the field capacity (20, 40,60 and $80 \% \mathrm{AD}$ ) a simple three rule will be performed to obtain the amount of water to be replenished to reach the amount of water available in the desired soil.

In the experiment, the variables corresponding to the radish culture (Raphanus sativus):

Height of the plant: estimated by a ruler graduated in $\mathrm{cm}$.

Number of sheets: counted visually, estimated in units.

Root length: obtained by quantifying the longitudinal length of the root, with the aid of a graduated ruler, in the sampling of all roots per plot, expressed in $\mathrm{cm}$.

Part of fresh aerial mass and root: obtained by quantifying the weight of all roots of each plot, expressed in grams.

Part of dry aerial mass and root: obtained after drying in a greenhouse with forced air ventilation in the period of 72 hours at $65^{\circ} \mathrm{C}$, and weighed in semi-analytical balance.

Root diameter: obtained by measuring the cross section of the root, with the aid of a digital caliper, with an accuracy of $0.01 \mathrm{~mm}$, in all roots per plot, expressed in mm.

With the obtained data will be carried out statistical analyzes through the test $\mathrm{F}$ and when significant apply if the regression analysis.

\section{RESULTS AND DISCUSSION}

Table 1 shows the significant $F$ values at the $5 \%$ probability level for percentages of available water in the soil (\% Water), cultivars and their interactions under productive characteristics of radish cultivated in a protected environment: Fresh mass aerial (FMA) It's root (FRM); Dry aerial mass (DAM) Root dry mass (RDM); Length of aerial part (LAP) It's root (LR).

Table 1. F-values of the analysis of variance of the percentage of available water in the soil (\% of water), cultivars and their interactions (Cultivation $\mathrm{x} \%$ of water) under the productive characteristics of radish cultivated in protected environment.

\begin{tabular}{lccccccc}
\hline \multicolumn{1}{c}{ SV } & FD & FMA & DAM & FRM & RDM & LAP & LR \\
\hline Grow crops & 1 & $0.35^{\text {ns }}$ & $1.64^{\text {ns }}$ & $1.97^{\text {ns }}$ & $12.62^{* *}$ & $2.87^{\text {ns }}$ & $0.28^{\text {ns }}$ \\
\% water & 4 & $2.24^{\text {ns }}$ & $2.47^{\text {ns }}$ & $5.32^{* *}$ & $8.27^{* *}$ & $0.93^{\text {ns }}$ & $5.06^{* *}$
\end{tabular}




\begin{tabular}{lccccccc} 
Grow crops x \% water & 4 & $6.81^{* *}$ & $7.42^{* *}$ & $1.24^{\text {ns }}$ & $1.51^{\text {ns }}$ & $3.26^{* *}$ & $1.72^{\text {ns }}$ \\
Block & 3 & $0.81^{\text {ns }}$ & $0.79^{\text {ns }}$ & $0.19^{\text {ns }}$ & $0.97^{\text {ns }}$ & $0.39^{\text {ns }}$ & $0.47^{\text {ns }}$ \\
Error & 27 & - & - & - & - & - & - \\
\hline CV $(\%)$ & - & 33.65 & 34.86 & 32.69 & 53.92 & 18.2 & 22.28 \\
\hline
\end{tabular}

SV: Source of variation; CV: coefficient of variation; FD: freedom degree; FMA: fresh aerial mass part; FRM: fresh root

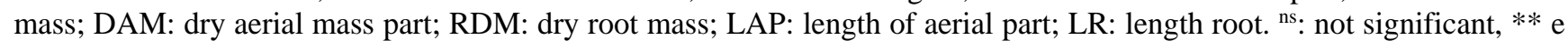
*, significant at $1 \%$ e $5 \%$, respectively, of probability by the $\mathrm{F}$ test.

The effect of radish cultivars was perceived only for the RDM characteristic, with the 'Cometo' cultivar having the best result for this characteristic, 3.07g, whereas the 'Crimson' cultivar had a root mass about 50\% lower than First, $1.64 \mathrm{~g}$, regardless of the percentage of water replenished. The interaction between the treatment factors studied was perceptible only for the aerial part response variables: FMA, DAM and LAP. However, an isolated effect of the percentage of water replenishment was observed for the root characteristics: FRM, RDM and LR, according to Table 1.

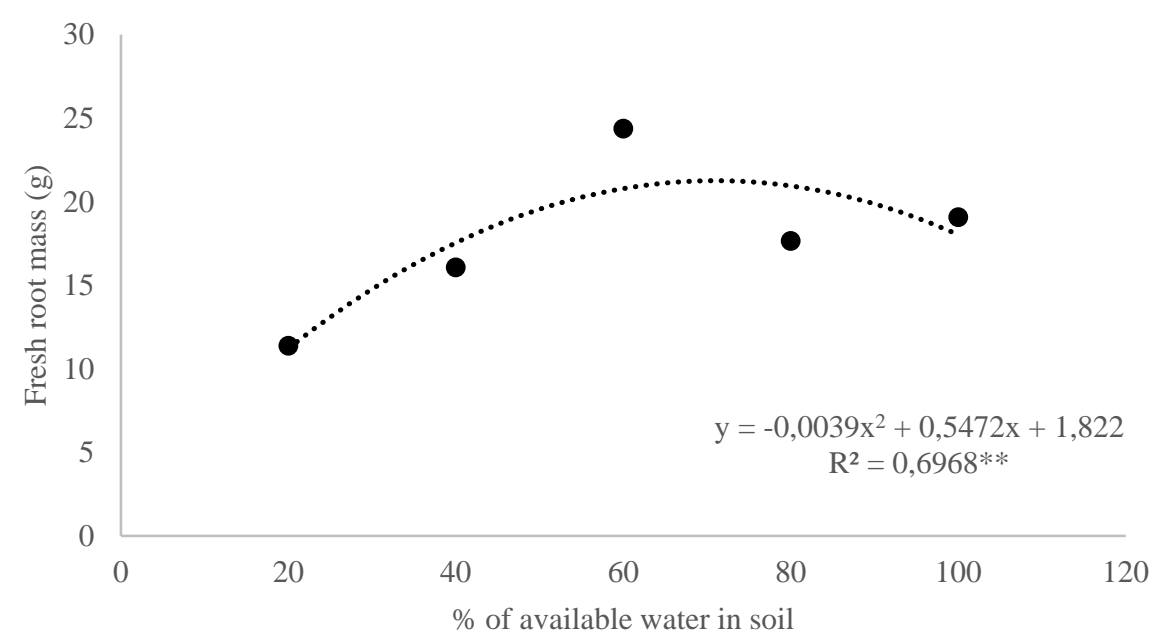

Figure 1. Fresh root mass of radish cultivars cultivated in protected environment under percentages of available water in the soil.

Figure 1 shows the quadratic adjustment equation for the effect of the percentage of available water in the soil under the FRM of radish cultivars cultivated in protected environment. It should be noted that the adjustment of the equation in relation to the observed data, given by the coefficient of determination was 0.6968, and the coefficients of the quadratic equation was significant at the
1\% probability level. Evaluating the equation, it can be seen that the percentage of available water that provided the greatest accumulation of fresh root mass was $71.04 \%$, which represents a root of $21.25 \mathrm{~g}$. Similar behavior was observed for the root dry mass, in which the blade that provided the highest DRM was 62.31\%, representing 3.456 g, according to Figure 2. 


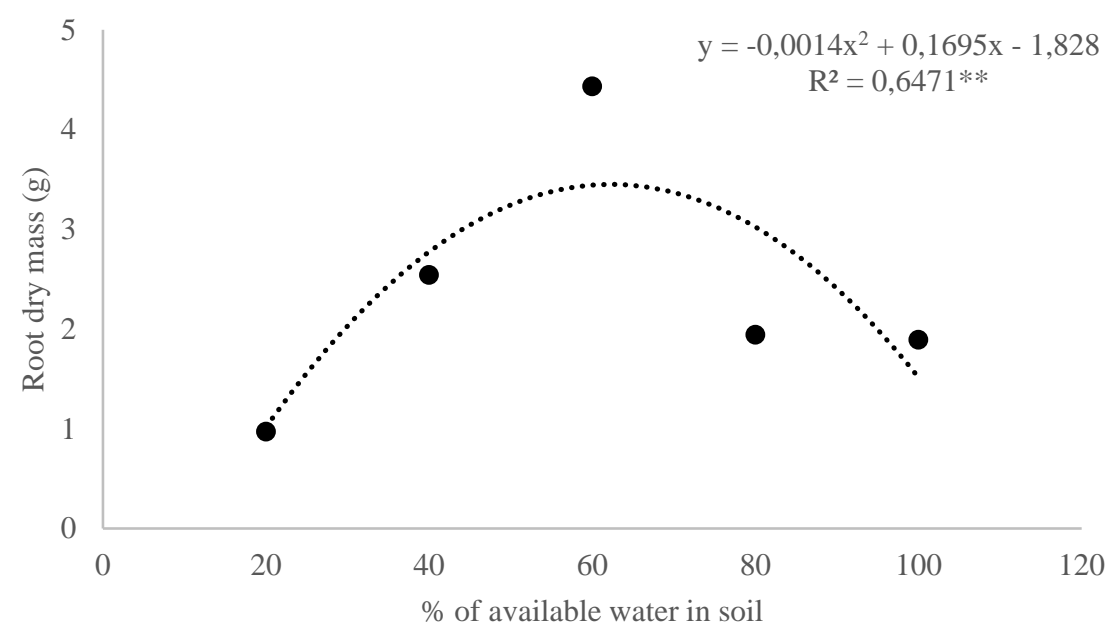

Figure 2. Root dry mass of radish cultivars cultivated in protected environment under percentages of available water in the soil.

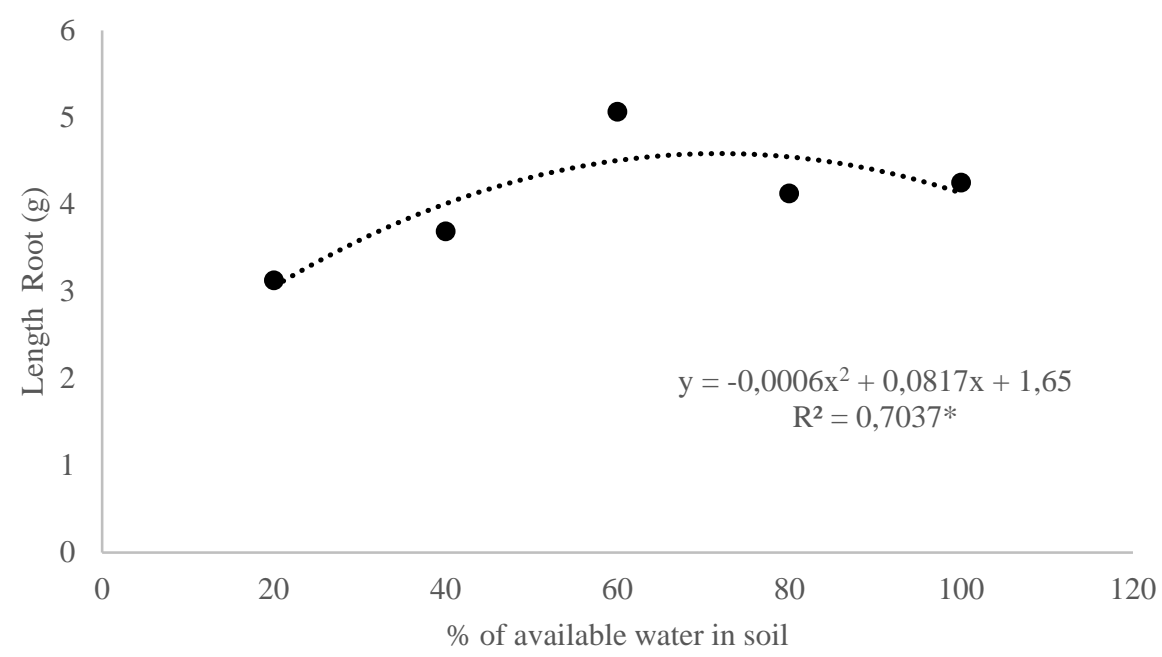

Figure 3. Root length of radish cultivars cultivated in protected environment under percentages of available water in the soil.

Klar et al. (2015) \& Lacerda et al. (2017) Evaluating irrigation slides as a function of the evapotranspiration on the green radish root biomass, found a linear adjustment, so that the green root mass production increased with the availability of water. According to Mousinho (2012), the plant responds positively to the increase of the applied water depth, increasing its production until reaching a maximum value, from which there is a drop in its yield, which was perceived in the present study. However, Rodrigues et al. (2012) observed that the level of soil water replenishment of less than $80 \%$ of the available water in the soil implies a reduction of the aerial mass and root, both fresh and dry, as well as root diameter. In the present study, according to figure 3, the root length was larger, $4.58 \mathrm{~cm}$, for the replacement percentage of $71.79 \%$ of soil water.

\section{CONCLUSION}

Among the analyzed variables, the leaf effect was significant for root length, fresh and dry mass, and $71.79 \%$, $71.04 \%$ and $62.31 \%$, respectively, were optimal blades. The effect of cultivars was observed for a variable dry mass of root, being a 
cultivar Cometo the one that presented better performance.

\section{ACKNOWLEDGMENTS}

CNPQ, FAPEG, CAPES. Federal Institute of Education, Science and Technology Goiano Camps Rio Verde. State University of Goiás - Camps Ipameri.

\section{REFERENCES}

ALISHAH, O., AHMADIKHAH, A. The effects of drought stress on improved cotton varieties in Golesatn province of Iran. International Journal of Plant Production, v.3, p. 17-26, 2009.

EMBRAPA. Centro Nacional de Pesquisa de Solos. Sistema brasileiro de classificação de solos. Brasília: Embrapa Produção de Informação; Rio de Janeiro: Embrapa Solos, 2006. $306 \mathrm{p}$

EMPRESA BRASILEIRA DE PESQUISA AGROPECUÁRIA - EMBRAPA. Manual de métodos de análises de solo. 2.ed. Rio de Janeiro: Ministério da Agricultura e do Abastecimento, 1997. 212 p.

JÚNIOR, T.J.S.; VENZON, M. 101 Culturas: Manual de tecnologias agrícolas. Belo Horizonte. EPAMIG, 2007. 800 p.

KLAR, A. E.; PUTTI, F. F.; GABRIEL FILHO, L. R. A.; SILVA JUNIOR, J. F.; CREMASCO, C. P. The effects of different irrigation depths on radish crops. Irriga, Botucatu, Ed. Especial, p. 150-159, 2015.

KLAR, A.E. Irrigação: frequência e quantidade de aplicação. São Paulo: Nobel, 1991. 156 p.

LACERDA, V. R.; GONÇALVES. B. G.; OLIVEIRA, F. G.; SOUSA, Y. B.; CASTRO, I. L. Características morfológicas e produtivas do rabanete sob diferentes lâminas de irrigação.
Revista Brasileira de Agricultura Irrigada, Fortaleza, v. 11, n. 1, p, 1127-1134, 2017.

MORENO-FONCECA, L. P. Respuesta de las plantas al estrés por déficit hídrico. Uma revisión. Agronomia Colombiana, Bogotá, v. 27, n. 2, p. 179-191, 2009.

MOUSINHO, F. E. P. Efeito da água no rendimento das culturas. Teresina, dez. 2012.

NOVAIS, R.F.; NEVES, J.C.L.; BARROS, N.F. Ensaio em ambiente controlado. In: OLIVEIRA, A.J.; GARRIDO, W.E.; ARAÚJO, J.D.; LOURENÇO, S. (Coord.). Métodos de pesquisa em fertilidade do solo. Brasília: Embrapa-SEA, p.189-253, 1991.

PIMENTEL, C. A relação da planta com a água. Seropédica, RJ: Edur, 2004. 191 p.

PINHEIRO, R. R.; SCHMIDT, D.; BOSCAINI, R.; BERTIN, R.; THIESEN, L. A.; ALTISSIMO, B. S.; HOLZ, E.; PROCHNOW, D.; DALLA NORA, F. E. Emergência do rabanete em diferentes substratos. In: XVII Seminário Interinstitucional de Ensino, Pesquisa e Extensão. XV Mostra de Iniciação Cientifica. X Mostra de Extensão, 2012, Cruz Alta. Anais eletrônicos... Cruz Alta: UNICRUZ. 2012.Disponível em: $<$ https://www.unicruz.edu.br/seminario/downlo ads/anais/ccaet/emergencia\%20do\%20rabanete \%20em\%20diferentes\%20substratos.pdf> .Acesso em: 28 de mar.2016.

RODRIGUES, R. R.; PIZETTA, S. C.; TEIXEIRA, A. G.; REIS, E. F.; HOTT, M. O. Produção de rabanete em diferentes disponibilidades de água no solo. Revista Enciclopédia Biosfera, Goiânia, v. 9, n. 17, p. 2121-2130, 2012.

SAAD, J. C. C.; SCALOPPI, E. J. Análise dos principais métodos climatológicos para estimativa da evapotranspiração potencial. In: CONGRESSO NACIONAL DE IRRIGAÇÃO E DRENAGEM, 8., Florianópolis. 
Anais...Florianópolis: Associação Brasileira de Irrigação e Drenagem, 1988. v.2, p. 999-1201.

SILVA, R. T. da.; SOUZA, A. A. T.; OLIVEIRA, F. de A. de.; TARGINO, I. S. de O.; SILVA, M. L. do N. Tolerância do rabanete ao encharcamento do solo. Revista Verde,
Mossoró, v. 7, n.1, p. 25-33, 2012.

SILVA, W.L.C.; MAROUELLI, W.A. Manejo da irrigação em hortaliças no campo e em ambientes protegidos. In: FARIA, M.A. (Coord.) Manejo de irrigação. Lavras: UFLA; SBEA, 1998. p.311-351. 